\title{
Mutation Induced Genetic Variability in Rice (Oryza sativa L.)
}

\section{S. El-Degwy}

Department of Agronomy, Faculty of Agriculture, Kafrelsheikh

University, Kafrelsheikh, Egypt.

\begin{abstract}
EEDS of the Egyptian rice cultivar Sakha 105 were treated with three gamma radiation doses; 15,20 and $25 \mathrm{Kr}$ to study the effect of gamma irradiation doses in the process of mutation on the growth, yield and yield-related characters of sakha 105 rice cultivar as well as to induce genetic variability for selecting plants with desirable character.
\end{abstract}

The effect of gamma -rays was observed in $\mathrm{M}_{1}$ and $\mathrm{M}_{2}$ generation for all the studied traits except panicle length in M1 and 1000-grain weight in both generations. The dose of $15 \mathrm{Kr}$ recorded the highest mean value of heading date and plant height in both generation and number of panicles/plant in $\mathbf{M}_{1}$ generation, this may be due to stimulatory effects of the low doses of gamma-rays which decrease with the increase of gamma irradiation dose.

The dose of $20 \mathrm{Kr}$ recorded significantly higher fertility percentage and number of branches/panicle in $\mathrm{M}_{2}$ generation and number of panicles/plant in $\mathrm{M}_{1}$ generation. The dose of $25 \mathrm{Kr}$ produced the highest number of panicles/plant and number of spikelets/panicle in $\mathrm{M}_{2}$ generation with in-significance difference with the control. While, it produced the lowest mean values for grain yield, number of filled grains/panicle, heading date and plant height in both generations. All the mutagenic treatments detected significantly lower grain yield than the un-treated plants in both generation.

The measurements of variation were, in general, higher in the treated plants compared with the control. Such estimates were maximized in case of fertility percentage, number of filled grains/panicle and grain yield. Among all treatments, the dose of $25 \mathrm{Kr}$ gamma radiation detected the highest variation.

Keywords: Gamma-rays, Genetic variability, Mutation, Rice, Yield and yield components.

In Egypt, breeding and cultivation of pure line varieties has increased rice production, but the yield of these varieties is now considered to have reached the plateau so, efforts to achieve further improvement on their yield potential were not satisfactory. Gamma- rays have drawn the attention as a rapid method to improve the qualitative and quantitative characters for many crops. The possibility of increasing the genetic variability of rice varieties by means of 
ionizing radiation had more consideration from plant breeder point of view. The most conspicuous effects of irradiation on the transmission of the genetic materials is its inhibiting action on meiosis (Attia et al., 1982). There are many kinds of ionizing radiation however, gamma rays are widely employed for mutation studies as they have shorter wave length and possess more energy per photon than x-rays and penetrate deep into tissue (Abdallah, 2000). Radiosensitivity widely varied not only between different species but also between different commercial varieties within the same species (Fujii \& Matsumura, 1958).

In Egypt, mutation breeding method was started for rice in 1960 s by Serry and Masoud when they subjected the old rice varieties Nahda and Agami to x rays \& gamma- rays (Serry \& Masoud, 1970). Most of gamma-ray irradiation doses were acute. High doses of radiation cased higher sterility of $\mathbf{M}_{1}$ plants. Low doses of irradiation in some cases stimulated the growth and yield of $\mathbf{M}_{1}$ plants (El-Keredy, 1990). Irradiating seeds with a suitable doses of gamma rays produces physiological and /or genetical changes in plant tissue which may be affected the yield of plant (Hammad \& El- Geddawi, 1988).

Induction of mutations for factors which govern the heredity of quantitative characters a promising tool for creating new genotypes. It is clear that mutagen, beside causing changes in major genes, induce mutation at loci governing quantitative characters. These micro-mutations can be detected in the form of increasing variance of $\mathrm{M}_{2}$ - generation.

Many early and semi dwarf rice lines were produced using gamma radiations treatments (Sanjeev, 2000; Shadakshari et al., 2001 and Bentota, 2006). Other studies showed that plant height, number of tillers and main panicle length decreased with increasing gamma radiation treatments up to $35 \mathrm{Kr}$ (Sabbour et al., 1993). Gamma-rays were more effective for inducing viable mutants (Pillai et al., 1993). Gupta \& Sharma (1994) reported that mutagenic treatments decreased plant height and number of panicles/plant.

Mutants with higher grain number/ panicle and grain yield than the control were detected (Deng \& Wu, 1990). High percentage of sterility and lower mean values for yield related traits were observed with increasing the doses of gamma rays (Sarawaga \& Soni, 1993).

The objectives of this investigation were to study the efficiency of gamma irradiation in the process of mutation in Sakha 105 Egyptian rice cultivar, as well as, to induce genetic variability for selecting mutants with desirable characters.

\section{Material and Methods}

This study was carried out at the Experimental Farm, Faculty of Agriculture, Kafrelsheikh University, Egypt during the two successive summer seasons of 2011 and 2012. Seeds of the Egyptian rice cultivar Sakha 105 were treated with gamma Egypt. J. Agron . 35, No.2 (2013) 
radiation at 15, 20 and /or $25 \mathrm{Kr}$ at the Middle East Regional Radioisotope Center for Arab Countries at Dokki, Giza. The treated and non-treated seeds (control) were grown in germination plastic trays in order to raise $\mathrm{M}_{1}$ plants. After 30 days the seedlings were individually transplanted into the permanent field in a complete randomized block design with four replication. Each experimental plot consisted of 25 rows. Each row was 3 meter long, with spacing of $20 \times 20 \mathrm{~cm}$. Cultural practices were performed as recommended. The seeds from the main, lateral-1 and lateral-2 tillers in each of 50 plants were randomly selected in each treatment for growing $\mathrm{M}_{2-}$ generation.

In 2012, the seeds of each of the 50 selected $M_{1}$ plants were grown on pots. Thirty days old seedlings were transplanted in a well prepared field. Progeny of the selected plants in each was transplanted in a progeny row trail with three replications, with spacing of $20 \times 20 \mathrm{~cm}$ and one seedling per hill. To determine $\mathbf{M}_{2}$ micro-mutation, observations on various quantitative traits were recorded on all the plants in each treatment.

The following observations were recorded: Days to $50 \%$ heading (day), plant height $(\mathrm{cm})$, panicle length $(\mathrm{cm})$, number of primary branches/panicle, number of spikelets/panicle, fertility percentage, number of filled rains/panicle, number of panicles/plant, 1000-grain weight $(\mathrm{g})$ and grain yield (g/plant).

\section{Statistical analysis}

$\mathrm{M}_{1}$ data were statistically analyzed according to the regular complete randomized block design, after the mean of each plot was calculated, Duncan's multiple rang test was used for the comparison between treatment means (Duncan, 1955).

In $\mathrm{M}_{2}$ micro-mutations were statistically analyzed by calculated minimum value, maximum value, the mean of the treatment $\left(\mathrm{X}^{-}\right)$, variance $\left(\mathrm{S}^{2}\right)$, standard error (S.E), coefficient of variability (C.V.\%) and the ratio of coefficient of variation of treatment and the control.

\section{Results and Discussion}

\section{$M_{1}$-generation}

Significant differences among gamma radiation treatments were detected for most of the studied characters (Tables 1 and 2). Only two characters; panicle length and 1000-grain weight detected in-significant differences. There was a gradual decrease for number of days to $50 \%$ heading and plant height with the increase in radiation dose. The first dose of radiation detected significantly higher mean values. So, low doses of radiations in some cases stimulated the growth of $\mathrm{M}_{1}$ plants (El-Keredy, 1990). Similar results were obtained by Labrada et al. (2001), who found a gradual decrease of plant height and days to heading with increase of radiation dose. Plant height was decreasing by increasing the dose of gamma-rays and in-significant differences in plant height were found 
between control and all treatments except the highest dose; $50 \mathrm{Kr}$, (Gomma et al., 1995).

TABLE 1. Effect of gamma-ray treatments on the studied growth characters of rice cultivar "Sakha 105 " in the $M_{1-}$ generation.

\begin{tabular}{|l|c|c|c|c|c|}
\hline Treatment & $\begin{array}{c}\text { Days to 50\% } \\
\text { heading(day) }\end{array}$ & $\begin{array}{c}\text { Plant height } \\
\text { (cm) }\end{array}$ & $\begin{array}{c}\text { Panicle length } \\
\text { (cm) }\end{array}$ & $\begin{array}{c}\text { No. of } \\
\text { primary } \\
\text { branches/ } \\
\text { panicle }\end{array}$ & $\begin{array}{c}\text { No. of } \\
\text { spikelets/ } \\
\text { panicle }\end{array}$ \\
\hline $15 \mathrm{Kr}$ & $94.5 \mathrm{a}$ & $93.4 \mathrm{a}$ & 24.4 & $10.6 \mathrm{~b}$ & $127.0 \mathrm{~b}$ \\
$20 \mathrm{Kr}$ & $90.3 \mathrm{bc}$ & $87.9 \mathrm{~b}$ & 24 & $10.9 \mathrm{~b}$ & $117.0 \mathrm{~b}$ \\
$25 \mathrm{Kr}$ & $89.0 \mathrm{c}$ & $86.2 \mathrm{~b}$ & 23.1 & $10.7 \mathrm{~b}$ & $122.0 \mathrm{~b}$ \\
Control & $91.0 \mathrm{~b}$ & $91.1 \mathrm{ab}$ & 23.3 & $12.2 \mathrm{a}$ & $127.4 \mathrm{a}$ \\
F-Test & $* *$ & $*$ & $\mathrm{~ns}$ & $* *$ & $*$ \\
\hline
\end{tabular}

$*, * *$ and ns : significant at the $0.05,0.01$ level of probability and not significant, respectively.

Means followed by a common letter(s) aren't significantly differed at 0.05 level.

TABLE 2. Effect of gamma-ray treatments on grain yield and yield-related characters of rice cultivar "Sakha 105 " in the $M_{1-\text { generation. }}$

\begin{tabular}{|l|c|c|c|c|c|}
\hline \multicolumn{1}{|c|}{ Treatment } & $\begin{array}{c}\text { Fertility } \\
(\boldsymbol{\%})\end{array}$ & $\begin{array}{c}\text { No. of filled } \\
\text { grains/panicle }\end{array}$ & $\begin{array}{c}\text { No. of } \\
\text { panicles/ } \\
\text { plant }\end{array}$ & $\begin{array}{c}\text { 1000-grain } \\
\text { weight }\end{array}$ & $\begin{array}{c}\text { Grain yield } \\
\text { (g/plant) }\end{array}$ \\
\hline $15 \mathrm{Kr}$ & $69.9 \mathrm{~b}$ & $88.7 \mathrm{~b}$ & $15.9 \mathrm{a}$ & 26.4 & $31.4 \mathrm{~b}$ \\
$20 \mathrm{Kr}$ & $34.8 \mathrm{c}$ & $40.0 \mathrm{c}$ & $16.1 \mathrm{a}$ & 25.9 & $14.1 \mathrm{c}$ \\
$25 \mathrm{Kr}$ & $26.2 \mathrm{c}$ & $31.9 \mathrm{c}$ & $14.3 \mathrm{~b}$ & 25.7 & $6.3 \mathrm{~d}$ \\
Control & $95.5 \mathrm{a}$ & $121.7 \mathrm{a}$ & $14.4 \mathrm{~b}$ & 26.7 & $36.2 \mathrm{a}$ \\
$\mathrm{F}-$ Test & $* *$ & $* *$ & $*$ & $\mathrm{~ns}$ & $* *$ \\
\hline
\end{tabular}

$* * *$ and ns : significant at the $0.05,0.01$ level of probability and not significant, respectively.

Means followed by a common letter(s) aren't significantly differed at 0.05 level.

In general, mutagenic treatments decreased the mean values of both number of spikelets and primary branches/panicle. However, the differences among the three gamma- rays treatments were not significant and the un-treated plants (control) detected significantly higher values; 12.2 and 127.4 for the aforementioned characters, respectively.

Results in Table 2 showed that spikelet fertility and number of filled grains/panicle decreased as gamma-ray doses increased from 15 to 20 and/or $25 \mathrm{Kr}$. While, the control plants revealed significantly higher mean values for these traits (95.5 and 121.7, respectively). Previous studies showed that spikelet fertility decreased with an increasing in gamma-ray doses from 10 to 20, 30, 40, and/or $50 \mathrm{Kr}$ (Shadakshari et al., 2001). Also, Sasikala \& Kalaiyarasi (2010) reported that seed fertility percentage were decreased with the increase of gamma radiation doses from 100 up to $350 \mathrm{~Gy}$ in linear fashion. 
Significant differences among the mutagenic treatments were detected for number of panicles/plant. Using a low dose of radiation $(15 \mathrm{Kr})$ significantly exhibited higher mean value (15.9) over all treatments but, the differences between 15 and $20 \mathrm{Kr}$ were not significant. This may be ensuring that low doses of radiation in some cases stimulated the growth of $\mathrm{M}_{1}$ plants.

There was a gradual decrease of grain yield/plant with the increase of radiation dose from 15 to 20 and/or $25 \mathrm{Kr}$. While, the non-treated plants recorded the highest mean value (36.2 g/plant). Another studies showed higher percentage of spikelet sterility and lower mean values for yield and yield-related characters with increasing the doses of gamma-rays (Sarawagia \& Soni, 1993).

\section{$M_{2}$-generation}

The effects of gamma-ray doses on growth yield and yield-related characters are presented in Tables 3 and 4 . All the studied characters were significantly affected by gamma radiation except of 1000 -grain weight. The mean number of days to $50 \%$ heading and plant height at $15 \mathrm{Kr}$ were significantly higher compared with the other treatments, while, the differences between 20 and $25 \mathrm{Kr}$ were not significant. The measurements of variation (range of variability and coefficient of variation) in the treated plants were higher than those of the control for the above traits as a coefficient of variability (C.V. \%) was greater several times in the treated plants than the control (Table 3). Another results showed that gamma-ray treatments widened the range of variability of heading date which could allow to select early mutants in advanced generations (Gomma et al.,1995). From the above results, it is clear that gamma-rays was able to create and extent an additional variations in heading date and plant height of the $\mathrm{M}_{2}$-generation.

Number of primary branches/panicle was significantly higher at the mutagenic treatments than those of the control plants but, the differences among the mutagenic treatments were not significant. However the opposite was true for panicle length, as un-treated plants detected longer panicles than the treated plants (Table 3). Also, the differences among the three doses of gamma-rays were not significant. In spite of, the mutagenic treatments recorded significantly higher number of primary branches/panicle and lower estimates of panicle length than the control plants, the range of variability for the mutagenic plants was mostly similar to that of the control. Previous results showed that variations and the mean values in most of the studied characters was increased by mutagenic treatments but, it decreased significantly for days to heading (Gupta \& Sharma, 1994). There was a gradual decrease for all growth indicators plant height, days to heading and panicle length with the increase of radiation dose (Labrada et al., 2001). 
Data presented in Table 3 showed that number of spikelets/panicle was significantly affected by mutagenic treatments in $\mathrm{M}_{2}$-generation. The mean value of this trait was increased at the dose of $25 \mathrm{Kr}$ in $\mathrm{M}_{2}$-generation. The range of variability was greater (96.2-159.6) compared with the other two dosage or the control. The coefficient of variation after treatments with gamma-rays was folded several times compared with the control. Similar studies showed that irradiation led to an increase in the coefficient of variability mainly in $\mathbf{M}_{2}$ generation (Amer \& El-Mohands, 1992).

TABLE 3. Effect of gamma-ray treatments on micro-mutation for the studied growth characters of "Sakha 105 " rice cultivar in the $\mathbf{M}_{2 \text {-generation. }}$

\begin{tabular}{|c|c|c|c|c|c|c|c|}
\hline Characters & Treatment & Min. & Max. & $\mathbf{X}^{-}$ & S. E & C.V.\% & $\begin{array}{l}\text { C.V. Treat/ } \\
\text { C.V. Cont. }\end{array}$ \\
\hline $\begin{array}{l}\text { Days to } 50 \% \\
\text { heading (day) }\end{array}$ & $\begin{array}{c}15 \mathrm{Kr} \\
20 \mathrm{Kr} \\
25 \mathrm{Kr} \\
\text { Control }\end{array}$ & $\begin{array}{l}75.0 \\
72.0 \\
80.0 \\
93.0\end{array}$ & $\begin{array}{c}111.0 \\
115.0 \\
120.0 \\
98.0\end{array}$ & $\begin{array}{l}95.0 \mathrm{a} \\
92.7 \mathrm{~b} \\
92.0 \mathrm{~b} \\
93.9 \mathrm{~b}\end{array}$ & $\begin{array}{l}1.24 \\
1.17 \\
1.13 \\
0.12\end{array}$ & $\begin{array}{l}7.14 \\
6.94 \\
6.70 \\
0.72\end{array}$ & $\begin{array}{l}9.92 \\
9.64 \\
9.30 \\
1.00\end{array}$ \\
\hline Plant height $(\mathrm{cm})$ & $\begin{array}{c}15 \mathrm{Kr} \\
20 \mathrm{Kr} \\
25 \mathrm{Kr} \\
\text { Control }\end{array}$ & $\begin{array}{l}77.0 \\
74.4 \\
68.4 \\
91.0\end{array}$ & $\begin{array}{l}107.0 \\
103.6 \\
102.6 \\
102.4\end{array}$ & $\begin{array}{c}92.5 \mathrm{ab} \\
88.4 \mathrm{~b} \\
89.2 \mathrm{~b} \\
95.8 \mathrm{a}\end{array}$ & $\begin{array}{l}1.41 \\
1.54 \\
1.19 \\
0.83\end{array}$ & $\begin{array}{l}8.38 \\
9.51 \\
7.29 \\
4.78\end{array}$ & $\begin{array}{l}1.83 \\
2.08 \\
1.96 \\
1.00\end{array}$ \\
\hline $\begin{array}{l}\text { Panicle length } \\
(\mathrm{cm})\end{array}$ & $\begin{array}{c}15 \mathrm{Kr} \\
20 \mathrm{Kr} \\
25 \mathrm{Kr} \\
\text { Control }\end{array}$ & $\begin{array}{l}19.0 \\
18.3 \\
19.5 \\
21.2\end{array}$ & $\begin{array}{l}22.8 \\
23.4 \\
22.8 \\
24.8\end{array}$ & $\begin{array}{l}20.6 b \\
20.7 b \\
21.1 b \\
22.8 a\end{array}$ & $\begin{array}{l}0.20 \\
0.25 \\
0.19 \\
0.13\end{array}$ & $\begin{array}{l}5.34 \\
6.67 \\
4.93 \\
3.33\end{array}$ & $\begin{array}{l}1.60 \\
2.00 \\
1.48 \\
1.00\end{array}$ \\
\hline $\begin{array}{l}\text { No. of primary } \\
\text { branches/panicle }\end{array}$ & $\begin{array}{c}15 \mathrm{Kr} \\
20 \mathrm{Kr} \\
25 \mathrm{Kr} \\
\text { Control }\end{array}$ & $\begin{array}{l}8.2 \\
9.4 \\
9.3 \\
9.8\end{array}$ & $\begin{array}{l}11.6 \\
12.0 \\
12.0 \\
11.6\end{array}$ & $\begin{array}{c}10.8 \mathrm{ab} \\
10.8 \mathrm{ab} \\
11.0 \mathrm{a} \\
10.6 \mathrm{~b}\end{array}$ & $\begin{array}{l}0.13 \\
0.17 \\
0.11 \\
0.10\end{array}$ & $\begin{array}{c}6.76 \\
8.8 \\
5.64 \\
5.28\end{array}$ & $\begin{array}{l}1.28 \\
1.67 \\
1.07 \\
1.00\end{array}$ \\
\hline $\begin{array}{l}\text { No. of } \\
\text { spikelets/panicle }\end{array}$ & $\begin{array}{c}15 \mathrm{Kr} \\
20 \mathrm{Kr} \\
25 \mathrm{Kr} \\
\text { Control }\end{array}$ & $\begin{array}{c}95.8 \\
101.8 \\
96.2 \\
128.6\end{array}$ & $\begin{array}{l}141.4 \\
154.0 \\
159.6 \\
143.2\end{array}$ & $\begin{array}{l}121.4 b \\
121.4 b \\
130.7 \mathrm{a} \\
135.9 \mathrm{a}\end{array}$ & $\begin{array}{l}0.36 \\
2.02 \\
2.49 \\
0.87\end{array}$ & $\begin{array}{c}9.03 \\
9.09 \\
10.42 \\
3.52\end{array}$ & $\begin{array}{l}2.57 \\
2.58 \\
2.96 \\
1.00\end{array}$ \\
\hline
\end{tabular}

Means followed by a common letter(s) aren't significantly differed at 0.05 level.

Min: minimum value

Max: maximum value

$\mathrm{X}^{-}$: the mean of the characters

C.V.: coefficient of variability

$$
\text { S.E: standard error }
$$


TABLE 4. Effect of gamma-ray treatments on micro-mutation for yield and yieldrelated characters of "Sakha 105 " rice cultivar in the $\mathrm{M}_{2}$-generation.

\begin{tabular}{|c|c|c|c|c|c|c|c|}
\hline Characters & Treatment & Min. & Max. & $\mathbf{X}^{-}$ & S. E & C.V.\% & $\begin{array}{l}\text { C.V. Treat / } \\
\text { C.V. cont. }\end{array}$ \\
\hline Fertility (\%) & $\begin{array}{c}15 \mathrm{Kr} \\
20 \mathrm{Kr} \\
25 \mathrm{Kr} \\
\text { Control }\end{array}$ & $\begin{array}{l}71.1 \\
46.0 \\
29.9 \\
92.1\end{array}$ & $\begin{array}{l}98.7 \\
97.8 \\
96.0 \\
97.8\end{array}$ & $\begin{array}{l}90.6 \mathrm{a} \\
90.5 \mathrm{a} \\
80.5 \mathrm{~b} \\
95.8 \mathrm{a}\end{array}$ & $\begin{array}{l}1.40 \\
1.98 \\
3.16 \\
0.24\end{array}$ & $\begin{array}{c}8.45 \\
11.97 \\
21.53 \\
1.36\end{array}$ & $\begin{array}{c}6.21 \\
8.80 \\
15.83 \\
1.00\end{array}$ \\
\hline $\begin{array}{l}\text { No. of filled } \\
\text { grains/ panicle }\end{array}$ & $\begin{array}{c}15 \mathrm{Kr} \\
20 \mathrm{Kr} \\
25 \mathrm{Kr} \\
\text { Control }\end{array}$ & $\begin{array}{c}83.6 \\
55.4 \\
57.8 \\
121.0 \\
\end{array}$ & $\begin{array}{l}134.0 \\
134.8 \\
138.0 \\
139.6 \\
\end{array}$ & $\begin{array}{l}110.1 \mathrm{~b} \\
109.8 \mathrm{~b} \\
104.3 \mathrm{~b} \\
130.2 \mathrm{a} \\
\end{array}$ & $\begin{array}{l}2.69 \\
2.96 \\
4.02 \\
0.93 \\
\end{array}$ & $\begin{array}{c}13.36 \\
14.78 \\
21.13 \\
3.90 \\
\end{array}$ & $\begin{array}{l}3.43 \\
3.79 \\
5.42 \\
1.00 \\
\end{array}$ \\
\hline $\begin{array}{l}\text { No. of panicles/ } \\
\text { plant }\end{array}$ & $\begin{array}{c}15 \mathrm{Kr} \\
20 \mathrm{Kr} \\
25 \mathrm{Kr} \\
\text { Control }\end{array}$ & $\begin{array}{l}10.6 \\
11.2 \\
11.2 \\
12.5\end{array}$ & $\begin{array}{l}18.8 \\
17.6 \\
18.3 \\
17.3\end{array}$ & $\begin{array}{c}13.9 \mathrm{~b} \\
14.0 \mathrm{~b} \\
14.7 \mathrm{ab} \\
15.5 \mathrm{a}\end{array}$ & $\begin{array}{l}0.36 \\
0.46 \\
0.33 \\
0.23\end{array}$ & $\begin{array}{c}14.32 \\
17.9 \\
12.44 \\
8.26\end{array}$ & $\begin{array}{l}1.73 \\
2.17 \\
1.51 \\
1.00\end{array}$ \\
\hline $\begin{array}{l}\text { 1000-grain } \\
\text { weight }(\mathrm{g})\end{array}$ & $\begin{array}{c}15 \mathrm{Kr} \\
20 \mathrm{Kr} \\
25 \mathrm{Kr} \\
\text { Control }\end{array}$ & $\begin{array}{l}24.8 \\
23.7 \\
24.4 \\
27.2\end{array}$ & $\begin{array}{l}30.0 \\
29.7 \\
30.1 \\
29.9\end{array}$ & $\begin{array}{l}28.5 \\
28.1 \\
28.2 \\
28.4\end{array}$ & $\begin{array}{l}0.19 \\
0.20 \\
0.28 \\
0.09\end{array}$ & $\begin{array}{l}3.72 \\
3.95 \\
4.54 \\
1.65\end{array}$ & $\begin{array}{l}2.25 \\
3.39 \\
2.75 \\
1.00\end{array}$ \\
\hline $\begin{array}{l}\text { Grain yield } \\
\text { (g/plant) }\end{array}$ & $\begin{array}{c}15 \mathrm{Kr} \\
20 \mathrm{Kr} \\
25 \mathrm{Kr} \\
\text { Control }\end{array}$ & $\begin{array}{l}17.4 \\
17.6 \\
20.6 \\
30.0\end{array}$ & $\begin{array}{l}41.2 \\
40.2 \\
42.6 \\
41.0\end{array}$ & $\begin{array}{l}29.6 \mathrm{~b} \\
28.8 \mathrm{~b} \\
30.5 \mathrm{~b} \\
35.9 \mathrm{a}\end{array}$ & $\begin{array}{l}1.18 \\
1.13 \\
1.13 \\
0.64\end{array}$ & $\begin{array}{c}21.86 \\
21.46 \\
26.8 \\
9.81\end{array}$ & $\begin{array}{l}2.57 \\
2.58 \\
2.96 \\
1.00\end{array}$ \\
\hline
\end{tabular}

Means followed by a common letter(s) aren't significantly differed at 0.05 level.

Min: minimum value

Max: maximum value

$\mathrm{X}^{-}$: the mean of the characters

C.V.: coefficient of variability

The dose of $25 \mathrm{Kr}$ detected significantly the highest reduction of fertility percentage (80.5\%) and number of filled grains/panicle (57.8) compared with the other treatments (Table 4). However, the differences among 15, $20 \mathrm{Kr}$ and the control were not significant for fertility percentage. So, gamma-ray doses had some stimulatory effects on seed fertility which decreased with increase in gamma irradiation dose (Chemma et al., 2003). The measurements of variability in the treated plants were higher than those of the control. The range of variability was maximized at the highest dose of gamma-rays and ranged from 57.8 to 138 for number of filled grains/panicle. So, the doses of gamma-rays in the present work were able to induce marked additional variation within their population. 
The values of number of panicles/plant were higher under $25 \mathrm{Kr}$ and the control compared with 15 and $20 \mathrm{Kr}$ treatments. The variability released after gamma-rays treatments was greater than that of the control. A great increment was detected in the range of variability of $\mathrm{M}_{2}$-generation at $25 \mathrm{Kr}$ dosage. Previous results showed high percentage of spikelet fertility and lower mean values for yield-related traits with increasing of the doses of gamma-rays (Sarawaga \& Soni, 1993). Increasing the dose of gamma-rays decreased the mean of number of filled grains/panicle, while, the mean of number of panicles/plant was increased, the coefficient of variability was increased by increasing the mutagenic dose for the studied characters, indicating the possibility of selecting promising mutants in further generations (Gomma et al., 1995). High coefficients of variability were recorded for number of filled grains/panicle and number of panicles/plant in $\mathrm{M}_{2}$-generation (Basak \& Ganguli, 1996). The highest coefficient of variation was given by sterility percentage (Mehetre et al., 1996). Previous results showed that radiation could induce both phenotypic and genotypic changes in rice (Britto et al., 2011).

Data presented in Table 4 showed that the mutagenic treatments did not change 1000-grain weight. Therefore, all treatments means had nearly the same value of 1000-grain weight and the range of variability for irradiated plants were similar to that of the control plants. So, the doses of gamma-rays in the present work were not able to induce marked variation within their population in 1000grain weight. Grain yield was significantly affected by mutagenic treatments. The non-treated plants recorded significantly higher grain yield than the treated plants. However, the differences among the three mutagenic treatments were not significant. The measurements of variation (range of variability and coefficient of variation) in the treated plants were higher than those of the control. The coefficient of variability on the treated plants was greater several times than the control. Similar findings were reported by Mohamed et al. (2006).

From the aforementioned results, It could be concluded that mutation technique have shown to be very useful in rice improvement, especially for characters controlled by closely linked genes that are difficult to break by gene recombination. Irradiation can be considered an effective source for generating genetic diversity among plants. Used irradiation by gamma-ray exhibited different genetic variability such as semi-dwarf, early heading and high yield plants. The induced genetic variability was more important as it is a basic perquisite for successful rice breeding program through direct selection or by hybridization with the commercial cultivars.

\section{References}

Abdallah, A. (2000) Breeding studies on rice. PhD. Thesis, Fac. of Agric., Menofiya Univ., Egypt.

Amer, I. and El-Mohands, S. (1992) Evaluation of irradiation populations and mutations induced after gamma-irradiation of Rape seeds. J. Agron. Egypt, 17(1), 77-88.

Egypt. J. Agron. 35, No.2 (2013) 
Attia, Y., Megahed, M. and El-Mogazi, M. (1982) The effect of gamma-rays on some characters of certain Egyptian cotton cultivars. Agricultural Research Review (Egypt), 60(9), 33-44.

Basak, A. K. and Ganguli, P. K. (1996) Variability and correlation studies of yield and yield components in induced plant type mutations of rice. Indian Agriculturalist, 40(3), 171-181.

Bentota, A. P. (2006) Mutation improvement of rice variety BW-267-3 for red pericarp grains and lodging resistance. Plant Mutation Reports, 1(1), 42-43.

Britto, A.J.D., Sujin, R. M. and Sebastian, S. R. (2011) Morphological and molecular variation of five rice varieties to ultra violet-B radiation stress. Journal of Stress Physiology and Biochemistry, 7(3), 80-86.

Chemma, A. A., Mohamed, R. and Zia-ul, Q. (2003) Effect of gamma-rays on $M_{1}$ generation in basmati rice. Pakistan Journal of Botany, 33(3), 811-813.

Deng, D. S. and Wu, W. (1990) Early mutant "Fu-06" used for hybrid rice breeding. News letter, 27, 6 .

Duncan, D.B. (1955) Multiple F-test. Biometrics, 11, 1-41.

El-Keredy, M. S. (1990) Induced useful mutations of some field crops in Egypt. Paper presented at the Fourth Conference of Agronomy, University of Cairo, Egypt, 1990. 1, pp. 237-253.

Fujii, T. and Matsumura, S. (1958) Radiosensitivity in plant. 1, Determination of LD-50 in cultivated plants. Jap. J. Genetics, 33, 389-397.

Gomaa, M.E., El-Hissewy, A. A., Kattab, A. B. and Abd-Allah, A. A. (1995) Days to heading and plant height of rice (Oryza sativa L.) affected by gamma-rays. Menofiya $J$. Agric. Res. 20(2), 409-421.

Gupta, S. and Sharma, D. K. (1994) Mutation induced variability in rice. Madras Agricultural Journal, 81(1), 50-52.

Hammad, D. H. A. and El-Geddawi, I. H. (1988) Effect of gamma irradiation on yield and chemical constituents of sugar beet. Paper presented at the Fourth Conf. of Nuclear Sciences and Application $6^{\text {th }}-10^{\text {th }}$ March, 1988.

Labrada, P., Wert, M. M. and Cepro, A. G. (2001) Radio-sensitivity of rice variety Perla Centro. Agricola , 28(2), 5-8.

Mehetre, S.S., Patil, A. B., Mahajan, R. C. and Shinde, P. R. (1996) Variability, heritability, character association and genetic divergence studies in $\mathrm{M}_{2}$ generation of gamma irradiation up land paddy. Crop Research Hisar, 12(2), 155-161.

Mohamed, O., Mohd, B.N., Alia, I., Azlan, S., Abdul-Rahman, H., Abdullah, M. Z., Oththman, O., Hadzim, K., Hbibuddin, H. I. and Golam, F. (2006) Development of improved rice varieties through use of induced mutation in Malaysia. Plant Mutation Report, 1(1), 27-33. 
Pialli, M. A., Subramanian, M. and Murugan, S. (1993) Effectiveness and efficiency of gamma rays and EMS for chlorophyll mutation on up land rice. Annals of Agricultural Research ,14(3), 302-305.

Sabbour, A. M., Mohamed, A. A. and Kattab, M. A. (1993) Radiosensetivity of two rice varieties treated with gamma-rays. Bulletin of Fac. of Agric., Cairo Univ. 44(3), 663-684.

Sanjeev, S. (2000) Gamma -rays induced mutating in Basmati rice (Oryza sativa L.). Indian Journal of Genetics and Plant Breeding, 66(2), 143-144.

Saragawa, A. K. and Soni, D. K. (1993) Induced genetic variability in $M_{1}$ and $M_{2}$ population of rice (Oryza sativa L.). Advances in Plant Sciences , 6(1), 24-33.

Sasikala, R. and Kalaiyarasi, R. (2010) Sensitivity of rice varieties to gamma irradiation. Electronic Journal of Plant Breeding, 4(1), 885-889.

Serry, E. and Masoud (1970) Mutations induced by irradiation and their significance in rice breeding. Rice Research Committee, Ministry of Agriculture and agrarian reform, $24^{\text {th }}-26^{\text {th }}$ Jan, 1970, Egypt.

Shadakshari, G. Y., Chandrappa, H., Kulkami, S. R. and Shashidhar, E. H. (2001) Induction of beneficial mutants. Indian Journal of Genetics and Plant Breeding, 61(3), 274-276.

(Received 31/12/2013; accepted 2/2/2014) 
استحداث اختلافات وراثية فى الارز باستخدام الطفرات

قابر الهيم سعديل الاجوى - كلية الزر اعة - جامعة كفر الثيخ - كفر الثيخ- مصر.

أجريت التجارب العملية لهذا البحث بالمزر عة التجريبية لكلية الزر اعةــ جامعة كفر

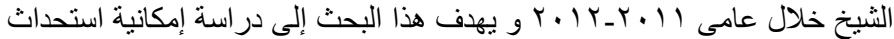

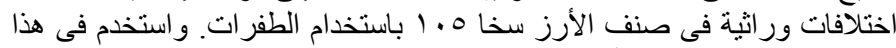

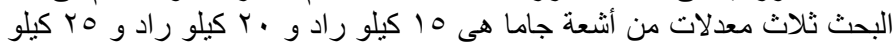

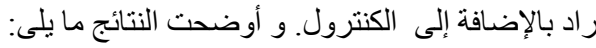

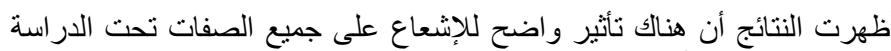

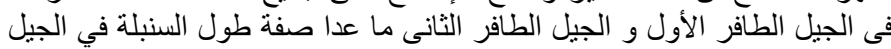

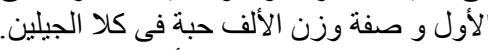

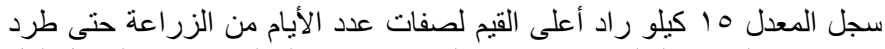

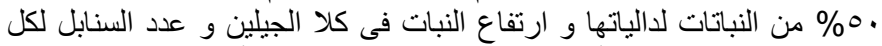

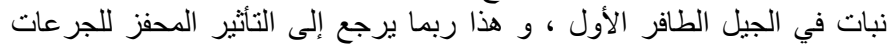

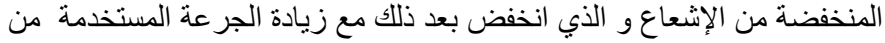
كالث الإشعاع.

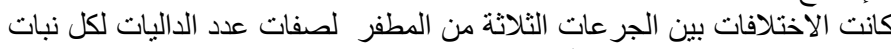

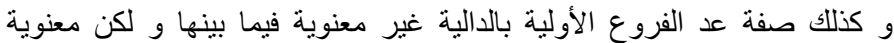
بالنسبة للكنترول.

سجلت الجرعة • ب كيلو راد أعلى القيم لصفة عدد الداليات لكل نبات في الجيل

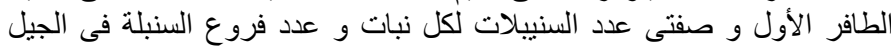

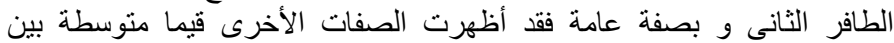
المعاملة الأولى و الكنتى و الجنرول.

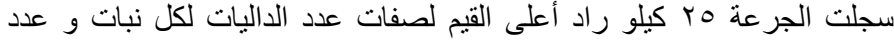

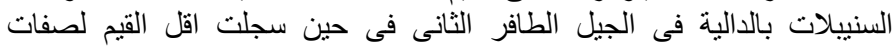

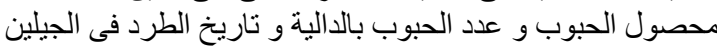

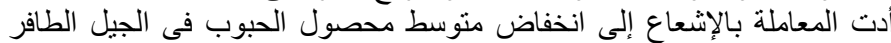

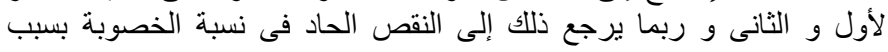

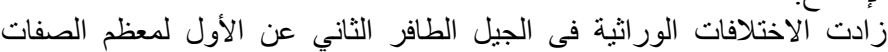

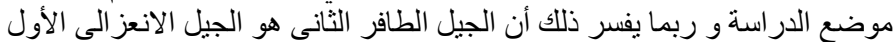

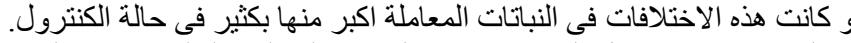

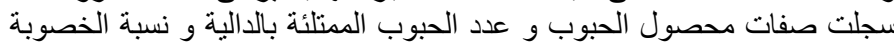
اكبر القيم لمقاييس التباين الور اثىى.

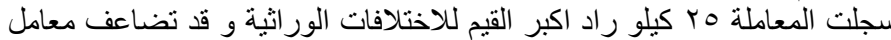

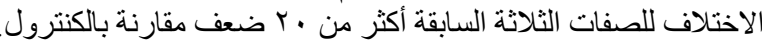

أوضحت الدراسة أن هنالك كمية كبيرة من الاختلافات الور اثية تم استحداثها

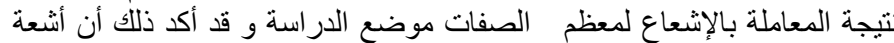

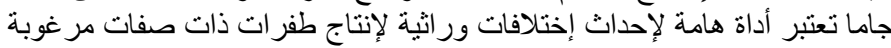

